\title{
Review of Tibetan Pastoralists and Development: Negotiating the Future of Grassland Livelihoods edited by Andreas Gruschke and Ingo Breuer
}

\author{
Yonten Nyima(i)
}

\author{
Book details \\ Gruschke A and Breuer I (eds.) \\ Tibetan Pastoralists and Development: Negotiating the Future of Grassland Livelihoods \\ Wiesbaden, Germany \\ Reichert Verlag, 2017 \\ 240 pages, ISBN: 9783954902422
}

Keywords: Tibetan pastoralism, Pastoral development, Pastoral livelihoods, Grassland, Caterpillar fungus, Humanwildlife conflict, Resettlement

The Tibetan Plateau constitutes the world's largest alpine ecosystem. Pastoralism on the plateau dates back to the eighth millennium BP (Meihe et al. 2014). For millennia, Tibetan pastoralists have sustained their livelihoods in the harsh environments and ever-changing political and economic conditions. However, since Chinese rule over Tibet, and particularly over the past two decades, political, economic, social and cultural transformations have been rapid and historically unprecedented. In this context, Tibetan Pastoralists and Development speculates on the future of Tibetan pastoralists through 15 empiricallybased chapters by Tibetan, Chinese and Western scholars across multiple fields. The book presents ongoing transformations and their socio-economic, cultural and ecological impacts on Tibetan pastoral livelihoods, and explores the complex roles of the Chinese state, emerging markets and rangeland resources in shaping these transformations.

While the over-riding theme of the book is pastoral livelihoods, specific themes include climate change, caterpillar fungus, resettlement, construction of houses and livestock shelters, rangeland enclosure, human-

Correspondence: yonten.nyima@nyu.edu

Robert F. Wagner Graduate School of Public Service, New York University, 295 Lafayette St, New York, NY 10012, USA wildlife conflict, education, gender and provision of social services in Tibetan pastoral societies. The book explores the question of possible futures of Tibetan pastoralists, through case studies on these themes. These case studies are from Tibetan areas in four of the five provinces in which historical and cultural Tibet is currently divided.

The book's strength is its collection of information that is otherwise not easily accessible to non-Chinese and non-Tibetan readers, as field research in Tibet by foreign social scientists is highly restricted. This is particularly the case in the Tibet Autonomous Region (TAR), where many places are officially closed to foreigners, as it has remained the most politically sensitive region in China due to the disputed legitimacy of Chinese rule over Tibet. The book could have stressed the political context in which Tibetan pastoralists live and work, as the two editors point out in the introduction (p. 10):

The future of pastoralism thus increasingly depends on how local conditions and practices can be shaped and managed in a participative way, with local pastoralists themselves being empowered to bring their very own 'way of doing', their creativity, into the 
equation and take control of their lives. Whether this is a future option in the current political climate in China remains an open question.

The role of China's authoritarian political system, including the absence of participatory governance and the imposition of uniformity over diversity, cannot be overstated. A fundamental problem in Tibetan pastoralism vis-à-vis the Chinese state is that Tibetan pastoralists are entrapped into accepting decisions made by others, with little space for participation in policymaking. Hence, the problem is political rather than technical in nature. However, no subsequent chapter points out the political aspects of Tibetan pastoralists' relationship with the Chinese state, which might be due to political sensitivity.

Missing citations, particularly where figures are cited from second-hand sources as well as some minor factual or editorial errors in some chapters, undermine the overall quality of an otherwise good book. In some chapters, official reports on rangeland conditions are cited uncritically, ignoring the fact that such reports are often influenced by political-economic factors. Finally, it would have been better if all place names had been provided in standard Tibetan spellings, with Chinese names in brackets, as this is a Tibet-themed book.

Chapters 1 and 2, by the two editors, both human geographers, provide an overview of the book and an introduction to the history and recent changes in Tibetan pastoralism. Chapter 2 concludes by suggesting that Tibetan pastoralists may have more than one future, ranging from sedentary pastoralists, to town dwellers, to fungus collectors. Chapter 3 by ecologist Wu Ning attempts to examine potential impacts of climate change and globalization on Tibetan pastoral livelihoods, through a case study from Dzoge on the eastern plateau. Chapter 3 concludes that Tibetan pastoralists' otherwise highly effective strategies for coping with effects of climate change may be undermined by globalization. However, the chapter does not really address globalization, but rather socio-economic changes brought about by domestic policies.

Chapter 4 by Daniel Winkler, a vegetation geographer, provides a detailed overview of the ecology, production, harvesting and trade of caterpillar fungus. It warns that the current caterpillar fungus boom may not be sustainable and suggests that Tibetans should use the current revenue from caterpillar fungus more wisely by investing it in initiatives that will benefit their overall well-being and the environment in the long run. Chapter 5 by anthropologist Janka Linke provides a detailed overview of caterpillar fungus commodity chains from Tibetan harvesters in Yulshul and Golok on the eastern plateau to consumer markets in
China. It shows that, contrary to some earlier findings, Tibetans hold a powerful position in both harvesting and trade of caterpillar fungus at the regional level. Chapter 6 by economist Luorong Zhandui and the two editors describes the development of the first regulations on access to caterpillar fungus in the TAR. They argue that the regulations protect local access to caterpillar fungus and thus contribute to the overall well-being of local pastoralists, although enforcement varies. To this reviewer, an underlying reason for the successful development of such regulations benefiting local pastoralists is a convergence of interests between government policy-makers and local pastoralists. Government policy-makers aim to achieve social stability through the regulations, as the chapter points out.

Chapter 7 by anthropologist Du Fachun examines the rationale, implementation and results of the resettlement of Tibetan pastoralists, through a case study from Mato in Golok. It shows how narratives of rangeland degradation purportedly due to over-grazing are employed to justify the resettlement of pastoralists. It points out how the living standard of pastoralists has declined after resettlement, although housing conditions, access to education, healthcare and transportation have usually improved. It concludes by suggesting reassessment of resettlement policy. Chapter 8 by Konchok Gelek, a development studies scholar, demonstrates the complexity of the effects of pastoral development initiatives, through a case study of Yulshul. He finds rangeland use rights' privatization has led to a decline in social capital due to an increasing awareness of private use rights, which has resulted in an increase in rangeland conflicts as the nature of the conflict shifts from the inter-community to inter-household level. Nonetheless, Tibetan pastoralists have self-organized to mitigate the side effects of rangeland use rights' privatization, as he points out. Chapter 9 by anthropologist Jarmila Ptackova explores the rationale, effects and implications of rangeland enclosure, based on fieldwork in Tibetan areas in Qinghai, Sichuan and Gansu provinces. The chapter shows that rangeland enclosure efforts have had three successive goals: to grow additional vegetation for winter feed or for sheltered young and weak livestock; as physical boundaries between households or villages; and to protect rangeland and ban grazing. Today, these three purposes overlap. Like Chapter 8, this chapter also reports mixed results of rangeland enclosure. Positive effects include rangeland use rights protection for poor households, and labour saving. Negative effects include reduced herding flexibility and possible negative impacts on ecosystems. The chapter concludes that rangeland enclosure is an important step towards sedentarization of Tibetan pastoralists.

Chapter 10 by ecologist Yan Zhaoli discusses the importance of active involvement of Tibetan pastoralists in decision-making and implementation processes in 
rangeland management. After reviewing ongoing challenges associated with policies, climate change and globalization (which, as in Chapter 3, is not really discussed) in rangeland management in Tibet and showing the self-organizing capacity of Tibetan pastoralists to mitigate these challenges, the chapter suggests that Tibetan pastoralists should be included in the entire process of policy formulation, implementation and revision, with policies implemented according to local conditions. However, as the chapter points out, such recommendations are easier said than done in China's authoritarian and upwardly accountable political system, which provides little room for meaningful public involvement in policy-making.

Chapter 11 by Dawa Tsering and John Farrington, both environmental studies scholars, is a wellresearched study of human-wildlife conflict in the Changtang nature reserve in the TAR, based on a household survey conducted in three counties in 2006 . The survey results showed a surge in the incidence of human-wildlife conflicts in the region since the upgrading of the nature reserve to national level in 2001 . Major reasons included improved protection of wildlife, wildlife being increasingly conditioned to human presence and human food and a growing overlap in habitats of wildlife and humans.

Chapter 12 by Shamo Thar, an education specialist, explores the important and complex role of education in the transformation of pastoral livelihoods in the context of China's ongoing policy of school centralization, based on a case study from Tsolho on the eastern plateau. The chapter lays out problems and challenges facing basic education in pastoral areas, including a high drop-out rate, financial burdens on poor households with children having to attend boarding schools far away from home, low education quality, exam-oriented education and the disconnect between education and pastoral life. It argues that the ongoing policy of centralizing rural primary schools has been ineffective in resolving these problems in poor pastoral areas.

Chapter 13 by Marc Foggin and Marion TorranceFoggin discusses the feasibility of providing social services to pastoralists in remote areas, based on the authors' own experiences both as development practitioners and researchers in Yulshul. The chapter demonstrates the feasibility of cost-effectively providing social services, particularly health and education, to remote pastoral areas as alternatives to resettlement of pastoralists. It argues that such an alternative is a pastoralist-friendly approach in terms of culture, society, economy and the environment in the long run. To this reviewer, while such an approach is technically feasible and should be supported and encouraged, it may prove politically infeasible, other than a few, small-scale exceptions. In the case of the TAR, 11\% of the region's total rural residents $(263,129$ out of 2.33 million) is to be relocated during the period 2016-2020 under a programme of poverty reduction through relocation (TARG 2016, RBS 2018), with 89\% of this group (236, 752) having reportedly already been relocated (China News 2019). This is the largest-scale resettlement of rural residents in the region's history. This shows that the policy of resettlement has only been intensified in recent years, contrary to the recommendations made in this volume. Not adequately addressed here or in the volume as a whole is the political nature of the problem, where policies are imposed with little input from the grassroots, which largely explains the persistence of status quo.

Chapter 14 by Tsering Yangdzom, a human geographer, clearly describes the gendered division of labour and gendered roles in family decision-making and beyond in pastoral Tibet through a case study from Nagchu in the TAR. The chapter finds that the clear-cut gender division of labour still prevails, while workload has decreased due to settlement and some modern facilities. Men make most family decisions and hold greater power over family finances, but they often consult with women about important decisions. Women's participation in community affairs is almost absent, with the majority never participating in any activities outside the domestic sphere.

Chapter 15 by Lhamotso, a feminist development studies scholar, is a well-articulated examination of gender norms and stereotypes in Amdo on the eastern plateau, directed at both English-reading educated Tibetans and international scholars working on Tibet. The examination is conducted through a critical analysis of Tibetan folklore, the deeply rooted Tibetan belief in karma, and analysis of everyday language. The chapter argues that gender inequity embedded in cultural and social values and beliefs constrains Tibetan women from exercising all their capabilities. It suggests that educated Tibetans should engage in critical dialogues on gender inequity in Tibetan societies, and encourages international scholars working on gender in Tibet to engage in collaborative conversations with Tibetan feminists to make their work more accessible to and useful to Tibetan women. This chapter showcases the work of an emerging generation of educated Tibetans inside Tibet who develop a perspective that is at once an insider's while also critically and theoretically informed.

In conclusion, this volume makes a substantial contribution to interdisciplinary scholarship on contemporary Tibetan pastoralism. I recommend it to scholars and students of pastoralism, Tibet studies and development studies, as well as anyone interested in contemporary Tibet or pastoralism.

Abbreviation

TAR: Tibet Autonomous Region

Acknowledgements

Not applicable 
Author's contributions

The author wrote, read and approved the final manuscript.

\section{Funding}

Not applicable

Availability of data and materials

Not applicable

Ethics approval and consent to participate

Not applicable

\section{Consent for publication}

Not applicable

\section{Competing interests}

The author declares that he has no competing interests.

Received: 23 August 2019 Accepted: 2 September 2019

Published online: 01 November 2019

\section{References}

China News. 2019. Deep-poverty areas in Tibet: Accurately attacking the "fortress". China news https://www.chinanews.com/gn/2019/07-04/8884551.shtml. Accessed 30 July 2019.

Miehe, G., S. Miehe, J. Böhner, K. Kaiser, I. Hensen, D. Madsen, J. Liu, and L. Opgenoorth. 2014. How old is the human footprint in the world's largest alpine ecosystem? A review of multiproxy records from the Tibetan Plateau from the ecologists' viewpoint. Quaternary Science Reviews 86: 190-209. RBS. 2018. Tibet statistical yearbook 2018. Lhasa: Regional Bureau of Statistics. TARG. 2016. The Tibet Autonomous Region's poverty alleviation plans in the 13th Five-Year Plan period. Lhasa: Tibet Autonomous Regional Government.

\section{Publisher's Note}

Springer Nature remains neutral with regard to jurisdictional claims in published maps and institutional affiliations.

\section{Submit your manuscript to a SpringerOpen ${ }^{\mathcal{O}}$ journal and benefit from:}

- Convenient online submission

- Rigorous peer review

- Open access: articles freely available online

- High visibility within the field

- Retaining the copyright to your article 